Received $\quad 07.01 .2016$

Reviewed 26.02.2016

Accepted 17.03.2016

A - study design

B - data collection

C - statistical analysis

D - data interpretation

$\mathbf{E}$ - manuscript preparation

F - literature search

\title{
Actions and measures for mitigation drought and water scarcity in agriculture
}

\author{
Leszek ŁABĘDZKI ${ }^{\text {ABCDEF }}$
}

Institute of Technology and Life Sciences, Kuyavian-Pomeranian Research Centre, ul. Glinki 60, 85-174 Bydgoszcz, Poland; e-mail: 1.labedzki@itp.edu.pl

For citation: $\quad$ Łabędzki L. 2016. Actions and measures for mitigation drought and water scarcity in agriculture. Journal of Water and Land Development. No. 29 p. 3-10. DOI: 10.1515/jwld-2016-0007.

\begin{abstract}
The paper characterizes the phenomena of droughts and water scarcity in Polish agriculture and their impacts on crop yield. Various preventive measures should be undertaken to mitigate the harmful effects of droughts and water scarcity. The most important is the development of water resources. To accomplish this aim, small scale water retention projects and irrigation development programs should be further implemented in many provinces of Poland. Effective use of irrigation water, optimization of water distribution, crop rotation, rehabilitation and modernization of the existing irrigation systems, soil reclamation are the examples of other measures. The pressure for increased water supplies is intensifying in Poland. That is why there is an urgent need to improve the uniform national plans of drought and water scarcity mitigation including guidelines on how to prevent and counteract the effects of water scarcity in agriculture and to release recommendations stating the most adequate measures to be undertaken.
\end{abstract}

Key words: agriculture, drought, mitigation, water scarcity

\section{INTRODUCTION}

Droughts can be considered as a temporary decrease of the average water availability due to e.g. rainfall deficiency. Water scarcity occurs where there are insufficient water resources to satisfy long-term average requirements. It refers to long-term water imbalances, combining low water availability with a level of water demand exceeding the supply capacity of the natural system [EC 2007].

Water scarcity is inextricably linked with different types of droughts (meteorological, soil, hydrological, agricultural). Water scarcity is not only caused by natural reasons but it is also the effect of human activities. Drought is considered to be a temporary natural phenomenon and is rather defined as availability of water less than average or usual [PEREIRA et al. 2002]. There are differences in the perception of drought and water scarcity. The characterisation of these phenomena is often controversial and not agreed. Some scientists, engineers, professionals and decision-makers equate drought with water scarcity or water deficit. Others point out that water scarcity is due to drought or simply prefer to write about drought water scarcity. In this publication water scarcity in agriculture is considered to be caused by a meteorological drought and is treated as an agricultural drought defined and quantified by soil moisture deficit and crop water stress affecting crop growth and yield [MARACCHI 2000].

The frequency of droughts and their severity increased in recent years and it is very likely that they will increase in near future due to predicted climate changes [BĄK, ŁABĘDZKI 2014; DÖLL 2002; IPCC 2013; LEHNER et al. 2006; LLOYD-HuGHES, SAUNDERS 2002; ŁABĘDZKI 2006; RICHTER, SEMENOV 2005]. There is a critical need for reliable information relevant the impacts of droughts and drought hazard 
mitigation. For counteracting drought impacts drought risk management plans are to be elaborated and implemented. The general objective of drought risk management plans is to support regional initiatives through the application of preparedness and mitigation measures.

In relation to drought it is said that drought management plans should contain the following elements: 1) drought related data and information concerning drought formation, exposure to drought and impacts of droughts, 2) a set of drought measures for various applications based on the information that is readily available, 3) methods for drought assessment and prediction, 4) drought hazard and vulnerability to drought, 5) identification of drought management approach (immediate response or decrease vulnerability) to recover or mitigate direct and indirect impacts of drought within economic, environmental and social contexts [ŁABĘDZKI, BĄK 2015]. The same or similar approach and elements should also apply to water scarcity.

Plans of drought and water scarcity mitigation should determine directions and measures as well as the intensity of organizational, technical, R\&D and innovative actions, which would aim at counteracting droughts and serve to limit their effects on the national economy and on agriculture in particular. It should contain descriptions of mitigation measures and of continuous, preventive actions to be carried out before, at the beginning of, during and after the cessation of a drought.

One of the specific objectives of the plan of mitigation of water deficit is to develop guidelines for developing and implementing different actions and measures leading to minimize negative effects of water deficit. Within drought risk management plans the recommendations for operational support system in drought risk management are to be elaborated. These recommendations should be sector-specific. They can be treated as guidelines oriented on utilizing all practical experiences.

Providing integrated guidelines for mitigating water scarcity is a step forward in attempt to establish drought management policy. The challenge for development of drought risk management scheme is integration of different approaches and concepts arising from different national, regional and sectoral contexts. The recommendations on how to assess drought risk, how to mitigate drought impacts and to create the catalogue of mitigation tools are the frameworks for drought risk management.

General objective of the study is to define and indicate possible mitigation actions and measures with the aim to minimize water scarcity in agriculture and its impacts in the background of practical experiences of utilizing different methods and tools in Poland.

\section{IMPACTS OF WATER SCARCITY IN AGRICULTURE}

The negative effect of droughts and water scarcity in Poland is complex and can be observed in various branches of the national economy. It is particularly visible in agriculture. Most commonly agricultural drought is defined as soil water deficit of a particular crop at a particular time period or moment, affecting crop yield and leading to significant decline in crop yield. A crop decrease is a final effect of soil water deficit and depends largely on the duration and intensity of the drought. Soil droughts and soil water deficits negatively affect crops, but the effect varies for various plants, soils and geographic regions. Autumn, winter and early spring droughts usually cause a decrease in winter and spring crops while spring droughts - a decrease in spring crops, the first hay cut and pasture efficiency. Summer droughts usually negatively affect potato crops, the second hay cut and the field fodder crops (e.g. maize).

The meteorological drought is expressed solely on the basis of the departure of rainfall from average and duration of the dry period. Agricultural drought is usually treated as an effect of water deficit, especially of crop water deficit. Agriculture drought links various characteristics of meteorological drought to agricultural impacts, focusing on precipitation shortages, differences between actual and potential evapotranspiration, soil water deficits etc. Any realistic definition of agricultural drought should account for the variable susceptibility of crops at different stages (phenophases) of crop development.

An analysis of the impacts of droughts in Polish agriculture shows that crop yield losses caused by meteorological drought of different intensity are evident [ŁABĘDZKI 2009]. A spatial differentiation of crop yield reduction depending on meteorological drought category and soils was determined. The less reduction is observed on the soil with greater total available soil water. Among field crops late potato is the most vulnerable crop to be damaged by drought. Its potential yield reduction can be more than $50 \%$ on light soils on most area of Poland during extreme meteorological drought. Least yield reduction is for winter wheat and winter rape. In most regions there is no negative effect of meteorological drought on yield of these crops. Only in central regions yield loss of these crops can reach $10-20 \%$ due to spring droughts.

The spatial distribution of yield reduction of all crops shows the central, central-east and central-west part of Poland, where agriculture drought risk is the greatest. These regions of Poland are most threatened by water deficits causing the greatest crop yield losses. In the two very dry years 1982-1983, an average decrease in grain crops was $5-30 \%$ in various regions of Poland and that of potatoes $-10-40 \%$ as compared to the average crops amounts in 1985-1987 [ $\mathrm{EA}-$ BĘDZKI 2006]. The drought in 1992 decreased the value of crops by $25 \%$. Total crops of grain, potatoes 
and bulk fodder, expressed in cereal units were lower in 1992 by $31 \%$ than those in 1991. Meadow hay crops (mean for the country) decreased by $27 \%$ in comparison to the average from 1986-1990. Droughts in the two years 2005-2006 caused considerable losses in crop production, especially central part of Poland, from west to east. In 2006 due to several-week lasting hot weather and lack of precipitation in June and July, the greatest losses in yields of spring cereals, maize, potatoes, sugar beets and grasslands were observed. According to the evaluations made by the Ministry of Agriculture and Rural Development, the losses in yields from meadows and pastures were 40 $100 \%$, spring cereals $-20-60 \%$, winter cereals -15 $50 \%$, rape $-15-45 \%$, potatoes and sugar beets -20 $60 \%$, vegetables - 30-60\%. Drought in 2015 caused $12 \%$ yield loss of cereals, $20 \%$ of vegetables, $25 \%$ of potatoes and $50-70 \%$ of silage maize.

\section{VULNERABILITY TO DROUGHT AND DROUGHT RISK}

Defining risk three determinants are taking into account: hazard, exposure and vulnerability. According to CARDONA et al. [2012], hazard refers to the possible occurrence of natural or human-induced physical events that may have adverse effects on vulnerable and exposed elements; exposure refers to the inventory of elements in an area in which hazard events may occur; vulnerability refers to the propensity of exposed elements such as human beings, their livelihoods, and assets to suffer adverse effects when impacted by hazard events.

Vulnerability shows the degree of susceptibility of society to a hazard, which could vary either as a result of variable exposure to the hazard, or because of coping abilities, which include protection and mitigation. The purpose of assessing vulnerability is to identify appropriate actions that can be taken to reduce vulnerability before the potential for damage is realized [WILHELMI, WILHITE 2002].

Taking into account the definition of vulnerability formulated with respect to climate change impacts [ESPON 2011; FÜSSEL, KLEIN 2006; IPCC 2007], vulnerability to drought can be defined as the degree to which a system is susceptible to, or unable to cope with, adverse effects of drought. Vulnerability is a function of the character, magnitude, and rate of drought to which a system is exposed, its sensitivity, and its adaptive capacity.

Vulnerability of agriculture to drought is generally referred to as the degree to which agricultural systems (crops) are likely to experience harm due to drought stress. When drought occurs, vulnerability of crops depends on several parameters, the most important ones being the ability of the particular type of crops to adapt to drought stress and the environment of its growth (soil, climate, available soil water). Because of the complexity of the issue of vulnerability, assessments are commonly subjective and vary be- tween regions and hazards. DOWNING and BAKKER [2000] state that vulnerability is a relative measure and the analyst must define its critical levels. Factors influencing drought vulnerability are numerous, and their inclusion may depend on data availability. The identification of key vulnerability factors are usually based on their significance for agricultural sector [SLEJKO et al. 2011; 2012]. Analysis of drought literature suggests that climate, soils, land use, cultivated crops, access to irrigation are the most significant factors of agricultural drought vulnerability that should be taken into account.

Agricultural drought risk is a combined effect of drought hazard (likelihood), exposure and drought consequence (vulnerability). Drought hazard is determined by frequency and severity of droughts. It can be referred to meteorological drought of a given intensity, probability and duration (of different time scale) that causes soil water deficit and crop water stress. Exposure factor usually means the area of cultivation of a given crop in a region. Vulnerability of agriculture described as the negative impacts of water scarcity on crop production is usually defined as potential crop yield reduction due to meteorological drought.

\section{ACTIONS AND MEASURES FOR DROUGHT AND WATER SCARCITY}

The actions for drought and water scarcity mitigation should be identified within of pre-impact programs that are intended to reduce vulnerability and impacts [WILHITE et al. 2014].

Various measures could be recommended, all of them are means to accomplish the strategic goal controlling the negative effects of water scarcity in agriculture.

Water scarcity mitigation measures can be divided into three groups, on account of the time of undertaking (actions):

- operational - undertaken when drought begins and in the time of its lasting,

- short-term - undertaken before drought in advance up to 5 years,

- long-term - undertaken in long perspective up to 25 years.

Among operational actions the most important and commonly used are irrigation, controlling water management in a watershed, flow control in rivers, controlling water intakes from rivers and lakes.

Short-term measures essentially to be taken up at local level include adjusting actions to optimize agricultural production without major systemic changes in the system of agricultural production. They may include earlier sowing, changing plant varieties, deep plowing, soil loosening, mulching, rainwater harvesting, artificial recharge of groundwater, comprehensive water saving schemes such as deficit irrigation, devising appropriate cropping patterns, making conjunctive use of surface and groundwater, prevention of evapo- 
ration losses from reservoirs, use of sub-optimal quality water for agricultural use, growing variety of crops resistant to drought reducing vulnerability against droughts.

Long-term mitigation measures relate to the larger systemic changes and may include: change in land use, changes in agricultural production systems, introduction of new crops, new irrigation management strategies, advanced technology and management of conducting irrigation, development of small water retention, watershed management and development, agro-climatic regional planning, creation of ground and surface water storages, integration of small reservoirs with major reservoirs, integrated basin planning, inter-basin transfer of water, development of community-based natural resources management plans, new land management techniques, developing consciousness among people about the scarcity of water.

Because of possible increase in water shortage in agriculture due to droughts and unfavourable climate changes the main actions and measures should lead to achieve the strategic aims:

- increase of local water resources and their availability,

- increase in water use efficiency,

- decrease in water needs for crops,

- intensification of irrigation (irrigation of larger surface).

To achieve these goals, the following actions are distinguished:

- increasing water resources retention (in open waters) available for agriculture, mainly for irrigation,

- increasing soil water retention and its availability for plants,

- modification of the technology of water use on farms and in fields,

- improvement in the social awareness of droughts, their effects and countermeasures.

Particular measures within the above actions are presented in Table 1. The actions can lead to achieve different strategic aims. They should increase water resources and their availability for agriculture, both in open waters (reservoirs, streams) and in soil, modify the needs of water users to force the need for saving water during droughts. A modification of the technology of water use on farms and in the field should play a great role. Minimizing the useless water outflow from fields, reclamation systems, streams etc. including drainage outflows and limiting crop water use are necessary.

Various actions and methods for counteracting drought effects in agriculture are now being implemented in Poland, all of them are means to accomplish the strategic goal - mitigating the negative effects of water deficit. The most visible actions now being accomplished are water retention programs throughout many regions of Poland [GWP CEE 2015]. These works are co-financed by the local, regional and national funds of environmental protection and water management.
The other important action is irrigation development as an effective measure to mitigate the negative effects of droughts in agriculture. Under the economic conditions of Polish agriculture irrigation of most field crops is an unprofitable measure. Irrigation of potatoes, vegetables and orchards is profitable [GRUSZKA 2004; JANKOWIAK et al. 2006; JANKOWIAK, RZEKANOWSKI 2006; LIPIŃSKI 2015]. In the group of vegetable crops the highest unit productivity was found for white cabbage, onion, celery, cauliflower and cucumber. It can be foreseen that the relation between the investment and operation costs of irrigation to benefits of irrigation will improve. From one side the reduction of prices of irrigation equipment can be expected; from the other side the market prices of agricultural products will make irrigation benefited for farmers. The economical side of irrigation is a very important and complex determinant of irrigation intensification. One should take into consideration such factors as productivity effectiveness, the use of different types of irrigation technology and their prices, operation and maintenance costs, prices for water drawn for irrigation, application of fertilizers, etc.

Irrigated area decreased by $75 \%$ since the beginning of the nineties, due to changes in national economy and economic conditions in agriculture [ŁABĘDZKI 2007]. According to the official state statistical data, on the average the area irrigated in 2012 was $0.5 \%$ of the total agricultural land area in the country [KACA 2015]. In the driest region of Poland - the Kujawsko-Pomorskie province - $1.1 \%$ of agricultural land area was irrigated [ŁABĘDZKI 2015]. Pressure irrigation is concentrated chiefly in the western and central part of the country, in regions with relatively low precipitation and of fertile soils. The effects of irrigation are associated with the quality of exploitation of irrigation systems. Where exploitation of facilities is proper and water supply is provided, one may avoid the negative effects of droughts and even obtain higher productivity. To achieve a high efficiency of these systems during a drought, systematic conservation of the network of ditches and facilities is necessary in the period preceding the drought. A lack of modernization and improper exploitation of the systems and facilities restrict competent water management and result in decreased crop production. The proper use of the systems and facilities allows for effective water management on irrigated areas and greater stability in yields. A decision support system can also plays considerable role in effective irrigation performance.

At present, increase in the area of irrigated land, especially in vegetable and fruit farming using drip irrigation, has been observed. It is assumed that the development of this type of irrigation will run parallel to the development and intensification of agriculture. Increased frequency and intensity of droughts, the intensification of agricultural production, being forced by the internal domestic and all-European free-market competition and the necessity of reaching high quality 
Table 1. Actions and measures for counteracting water scarcity impact in agriculture and their expected effects

\begin{tabular}{|c|c|c|c|c|}
\hline Action & Measures & Effects & $\begin{array}{l}\text { Duration of } \\
\text { action }\end{array}$ & Main goal \\
\hline $\begin{array}{l}\text { Increasing water } \\
\text { resources retention } \\
\text { (in open waters) } \\
\text { available for agri- } \\
\text { culture }\end{array}$ & $\begin{array}{l}\text { - construction of small water reten- } \\
\text { tion reservoirs } \\
\text { - construction of water structures to } \\
\text { restrict water outflow from fields } \\
\text { - different small water retention } \\
\text { measures }\end{array}$ & $\begin{array}{l}- \text { adaptation of existing sources of } \\
\text { small retention to requirements for } \\
\text { agriculture with the possibility of } \\
\text { their enlargement in the future } \\
\text { - } \text { more water available for irrigation } \\
\text { - collection of water in local reser- } \\
\text { voirs during periods of its excess } \\
\text { (in spring and after abundant in- } \\
\text { tensive precipitation) } \\
\text { - water retention and slowing runoff } \\
\text { in small streams }\end{array}$ & $\begin{array}{l}\text { long-term } \\
\text { short-term }\end{array}$ & $\begin{array}{l}\text { increase of local } \\
\text { water resources and } \\
\text { their availability }\end{array}$ \\
\hline $\begin{array}{l}\text { Increasing soil } \\
\text { water retention and } \\
\text { its availability for } \\
\text { plants }\end{array}$ & $\begin{array}{l}\text { - technologies of soil cultivation that } \\
\text { increase soil moisture and the de- } \\
\text { gree of water utilization (e.g. soil } \\
\text { loosening, deep plowing, organic } \\
\text { fertilization) } \\
\text { - plant species selection in crop rota- } \\
\text { tion (drought resistance plants, } \\
\text { plants with a shorter vegetative pe- } \\
\text { riod, lower water requirements, } \\
\text { a deeper root system) } \\
\text { - fertilization and reclamation meas- } \\
\text { ures that aid the development of a } \\
\text { strong root system } \\
\text { - introduction of deep-rooted plants } \\
\text { with low water requirements } \\
\text { - irrigation }\end{array}$ & $\begin{array}{l}\text { - improvement of soil structure } \\
\text { - improvement of physical and wa- } \\
\text { ter properties of soil layers } \\
\text { - increased infiltration } \\
\text { - } \text { enlarging the active layer of roots } \\
\text { water uptake } \\
\text { - deeper rooting } \\
\text { - increased amount of water avail- } \\
\text { able for plants } \\
\text { - increased plant water use effi- } \\
\text { ciency (more crop for a drop) } \\
\text { - decreased losses in crop yield }\end{array}$ & short-term & $\begin{array}{l}\text { increase of local } \\
\text { water resources and } \\
\text { their availability. } \\
\text { increase in water } \\
\text { use efficiency; } \\
\text { decrease in water } \\
\text { needs for crops; } \\
\text { intensification of } \\
\text { irrigation }\end{array}$ \\
\hline $\begin{array}{l}\text { Modification of the } \\
\text { technology of } \\
\text { water use on } \\
\text { farms, in fields, in } \\
\text { catchments }\end{array}$ & $\begin{array}{l}\text { - modernization of irrigation and } \\
\text { water distribution systems to in- } \\
\text { crease their effectiveness for supply } \\
\text { and out-flow of water } \\
\text { - improvement of operation and man- } \\
\text { agement of irrigation and water sys- } \\
\text { tems } \\
\text { - usage of modern energy- and water- } \\
\text { saving methods and techniques of } \\
\text { irrigation } \\
\text { - implementation of new irrigation } \\
\text { management techniques } \\
\text { - improvement and implementation of } \\
\text { water distribution procedures to- } \\
\text { wards dynamic and flexible water } \\
\text { resources management with the use } \\
\text { of multi-criteria optimization and } \\
\text { modern automatic systems of moni- } \\
\text { toring of the state of water systems } \\
\text { (groundwater table depths, stream } \\
\text { water stages and stream flow dis- } \\
\text { charge, monitoring of water struc- } \\
\text { tures) } \\
\text { - adjustment of water system control } \\
\text { algorithms to changing climate con- } \\
\text { ditions and extreme weather events } \\
\text { - development of regional (local) } \\
\text { systems of meteorological monitor- } \\
\text { ing for the need of water system } \\
\text { management } \\
\text { - development of telecommunication } \\
\text { systems } \\
\text { - usage of remote-sensing methods } \\
\text { and GIS in water system control }\end{array}$ & $\begin{array}{l}\text { - } \text { saving water } \\
\text { - increasing water use efficiency by } \\
\text { multiple use of water } \\
\text { - } \text { minimizing useless water dis- } \\
\text { charges from reclamation systems, } \\
\text { including drainage outflows } \\
\text { - limiting water consumption for } \\
\text { evapotranspiration } \\
\text { - improvement in energy- and water } \\
\text { consumption efficiency of irriga- } \\
\text { tion } \\
\text { - improvement of water use effi- } \\
\text { ciency by crops } \\
\text { - improvement of existing infra- } \\
\text { structure for storage and distribu- } \\
\text { tion of water } \\
\text { - increasing available water re- } \\
\text { sources (in soils, streams, reser- } \\
\text { voirs) }\end{array}$ & $\begin{array}{l}\text { short-term } \\
\text { operational }\end{array}$ & $\begin{array}{l}\text { increase in water } \\
\text { use efficiency; } \\
\text { decrease in water } \\
\text { needs for crops; } \\
\text { intensification of } \\
\text { irrigation }\end{array}$ \\
\hline $\begin{array}{l}\text { Improvement in } \\
\text { the social aware- } \\
\text { ness of droughts, } \\
\text { their effects and } \\
\text { countermeasures }\end{array}$ & $\begin{array}{l}\text { - } \text { training } \\
\text { - brochures, leaflets, bulletins } \\
\text { - internet } \\
\text { - radio, television, newspapers } \\
\text { - } \text { development and implementation of } \\
\quad \text { decision support systems (DSS) }\end{array}$ & $\begin{array}{l}\text { raising the awareness of the society } \\
\text { of the issues of drought and its miti- } \\
\text { gation }\end{array}$ & $\begin{array}{l}\text { long-term } \\
\text { short-term } \\
\text { operational }\end{array}$ & all \\
\hline
\end{tabular}

Source: own study. 
of the majority of agricultural products are the factors accelerating the development of irrigation. The significance of irrigation will increase with the intensification of agriculture (e.g. in horticulture, orchards, seed crops) and with negative effects of climate changes. Predicted climate changes and increase in frequency and intensity of droughts in our climate zone will cause increased crop water demands, irrigated area and irrigation water requirements. It is estimated that in many regions of Poland, further development of irrigation could be determined and restricted to a great extent by the availability of water resources. In many cases the factor preventing irrigation is the lack of water due to the co-occurrence of drought and low water tables in rivers and consequently, the decreased useful capacity of lakes and retention reservoirs. Then, the important role in water management is regulation of outflow, which consists of creating favourable conditions for water retention and controlling water discharge in the periods of water excess - in the spring and after a large amount of precipitation, thus in retaining water in the soil and in the network of ditches. It can be achieved by construction of small water retention reservoirs and small dam up flowing water by small water structures to restrict water outflow from fields [GWP CEE 2015].

Drainage also plays a large role in mitigating the negative effects of droughts on crop yields. The role of draining consists of lowering the ground water table in the spring, which allows field works to be started earlier and thus earlier plant growth and root development, enabling the root systems to take up water from the deeper parts of soil during drought conditions. However, on the other hand, one should be aware that if water is drained from the soil, less water remains in the soil and drought could appear earlier.

In plant technologies, processes should be recommended that allow one to obtain the beneficial effects of plant growth under drought conditions. Economic losses due to decreased yields can be minimized by the introduction of deep-rooted plants with low water requirements in the most affected regions. Planting tolerant or climate-robust variety, fertilizers application and adequate supply of water can help the farmers to combat the effect of water deficit. New crop varieties, seasonal changes and sowing dates are the adaptive methods employed. Fertilizer application, adequate density of plants, tillage methods, in-field small retention measures and other field operations are the adaptive methods used to reduce the effect of water scarcity in agriculture.

Agro-reclamation measures, mostly soil loosening and deep ploughing can also mitigate the negative effects of drought. These measures consist of the improvement of the soil structure and of the physical and water properties of the deeper soil layers, which enables deeper rooting of plants and increases the amount of water available for plants. However, they can also give some negative effects as reduction of the upward water flux, increasing deflation.
Moreover, various technical, reclamation, hydrologic and anti-erosion measures can be used, which mitigate negative effects of droughts in agriculture. They serve to improve water cycling and the water balance within the watershed, the reclamation system and the soil. They should lead to a change and optimization of productive space utilization, to modifications in crop rotation, to selection of the proper drought resistant plant species and varieties and to changes in agricultural technique. The preparation of a list of plant varieties commonly cultivated on a given area and resistant to drought is desirable. All complex reclamation measures like forestation, introduction of grasslands and proper fertilization fall within these types of actions. They all may restrict the negative effects of droughts on a given area to a large degree.

One of the basic preventive actions is drought forecasting and early warnings. Forecasting and early warnings are of great importance in planning and preparing to undertake actions aimed at avoiding or minimizing the negative effects of droughts.

Actual determinants of various activities against drought and water scarcity in Polish agriculture are strictly connected with the state of water management in agriculture, particularly with the state of landreclamation (amelioration). Basic reasons for the restricted possibilities of drought counteraction on agricultural areas lie in the negligence of the proper use of agricultural water systems and reclamation systems and facilities. Improvement of management, operation and maintenance of these systems will make mitigation measures more effective.

One has to take into account some risk, restrictions and losses in crops and incomes. That is why an acceptable level of losses on various management levels - in a region, in a commune, on a farm - should be determined within the drought mitigation plans. A list of priorities is to be prepared to determine the permissible level of losses in agricultural production. This would enable planning the respective tasks and an optimum allocation of means for their accomplishment.

Institutional activities will be of substantial importance in developing and in accomplishing the plans for drought and water scarcity control. Their contributions will include using of operational planning models of collection and water transfer within a watershed, decisive models of water management in retention reservoirs and water systems, changes in water distribution management from the local level to the central one (within a catchment), changes in the organization of the administrative water management and new legal regulations. Institutional solutions should consider local problems within a region, which result from the frequency of droughts, their character and the impact they exert upon various water users as well as those problems originating from the expected economic losses due to the water deficit. 


\section{CONCLUSIONS}

Actions and measures for mitigating the effects of droughts and water scarcity as well as uncertainties as to how the climate will change and how it will influence agriculture are the challenges that planners, designers, farmers, agricultural and extension services will have to cope with. How agriculture and agricultural water management will have to adapt to climate changes is the serious question to be answered in the near future.

All of the above mentioned actions and measures should be addressed in long-term strategy for drought control, for mitigating effects of droughts, water scarcity and observed climate change as well as for adaptation of agriculture and agricultural water management to predicted climate change. Preparation of such a strategy together with programs for the accomplishment of the relevant tasks is indispensable in the nearest future in Poland.

In view of the drafted actions undertaken in Poland during droughts aimed at limiting their negative effects, one may conclude that they do not form a consistent system and result in partial strategies of drought control. The problems of drought control and the resulting activities are a challenge to Poland to have a drought mitigation strategy and to look for new and more perfect solutions and their implementation in regions with a high risk of droughts. This basis for any activity should be a strategic program, which would determine how and in which way to achieve the requested strategic goals.

There is an urgent need to improve and to implement the uniform national plans of drought and water scarcity mitigation including a national water saving policy and its legal aspects, the issuing of drought advisories and warnings, the creation of guidelines on how to prevent and counteract the effects of drought and water scarcity and to release recommendations stating the most adequate measures to be undertaken. It may be expected that further work should result in documents providing for the implementation of regional small retention development programs and irrigation development programs.

\section{REFERENCES}

BĄK B., ŁABĘDZKI L. 2014. Prediction of precipitation deficit and excess in Bydgoszcz Region in view of predicted climate change. Journal of Water and Land Development. No. 23 p. 11-19.

CARdona O.D., van Aalst M.K., BiRKMANN J., FordhaM M., McGregor G., Perez R., Pulwarty R.S., SchipPer E.L.F., SinH B.T. 2012. Determinants of risk: exposure and vulnerability. In: Managing the risks of extreme events and disasters to advance climate change adaptation. Eds. C.B. Field, V. Barros, T.F. Stocker, D. Qin, D.J. Dokken, K.L. Ebi, M.D. Mastrandrea, K.J. Mach, G.-K. Plattner, S.K. Allen, M. Tignor, P.M. Midgley. A Special Report of Working Groups I and II of the Intergovernmental Panel on Climate Change (IPCC) [online]. Cambridge University Press, Cambridge, UK, and New York, NY, USA p. 65-108. [Access 04.04. 2016]. Available at: https://www.ipcc.ch/pdf/specialreports/srex/SREX-Chap2_FINAL.pdf

DOWNING T.E., BAKKER K. 2000. Drought discourse and vulnerability. In: Drought: a global assessment, natural hazards and disasters series. Ed. D.A. Wilhite. Chapter 45. Routledge Publishers, U.K. p. 194-202.

DöLL P. 2002. Impact of climate change and variability on irrigation requirements: a global perspective. Climatic Change. No. 54 p. 269-293.

EC 2007. Water scarcity and droughts. Second Interim Report. DG Environment pp. 93.

ESPON 2011. ESPON Climate. Climate change and territorial effects on regions and local economies. Scientific Report [online]. Dortmund. TU University. ISBN 9782-919777-04-4. [Access 04.04.2016]. Available at: https://www.espon.eu/export/sites/default/Documents/ Projects/AppliedResearch/CLIMATE/ESPON Climate_Final_Report-Part_C-ScientificReport. pdf

FÜSSEL H.-M., KLEIN R.J.T. 2006. Climate change vulnerability assessments: an evolution of conceptual thinking. Climatic Change. Vol. 75. Iss. 3 p. 301-329.

GRUSZKA J. 2004. Efektywność systemów produkcji roślinnej w gospodarstwach rolnych stosujących nawodnienia deszczowniane [Efficiency of crop production systems in farms using sprinkler irrigation]. Woda-ŚrodowiskoObszary Wiejskie. T. 4. Z. 2b(12) p. 69-80.

GWP CEE 2015. Natural small water retention measures combining drought mitigation, flood protection and biodiversity conservation. Guidelines. ISBN 978-80-97206 03-1 pp. 25.

IPCC 2007. Climate change 2007 - Impacts, adaptation and vulnerability. Contribution of working group II to the Forth Assessment report of the Intergovernmental Panel on Climate Change. Cambridge University Press, Cambridge, United Kingdom and New York, NY, USA pp. 961.

IPCC 2013. Climate change 2013: The physical science basis. Contribution of working group I to the Fifth Assessment report of the Intergovernmental Panel on Climate Change. Eds. T.F. Stocker, D. Qin, G.-K. Plattner, M. Tignor, S.K. Allen, J. Boschung, A. Nauels, Y. Xia, V. Bex, P.M. Midgley. Cambridge. Cambridge Univ. Press pp. 1535.

JANKOWIAK J., BIEŃKOWSKI J., JANKOWIAK S. 2006. Współczesne uwarunkowania stosowania nawodnień deszczownianych $\mathrm{w}$ rolnictwie [Present conditions of sprinkler irrigation in agriculture]. Roczniki AR w Poznaniu. R. 380. Rolnictwo. $\mathrm{Nr} 66$ p. 121-129.

JANKOWIAK J., RZEKANOWSKI Cz. 2006. Ekonomiczne efekty nawadniania. W: Nawadnianie roślin [Economic effects of irrigation. In: Crop irrigation]. Eds. S. Karczmarczyk, L. Nowak. Warszawa. PWRiL p. 461-479.

KACA E. 2015. Stan melioracji i gospodarowania wodą w rolnictwie w skali kraju i województw w świetle danych Ministerstwa Rolnictwa i Rozwoju Wsi. W: Rozwój melioracji i gospodarowania wodą w świetle wojewódzkich opracowań strategicznych [The status of melioration and water management in agriculture in the country and provincial scale from data of the Ministry of Agriculture and Rural Areas. In: Development of melioration and water management in view of provincial strategic plans]. Ed. E. Kaca. Woda-Środowisko-Obszary Wiejskie. Rozprawy naukowe i monografie. Nr 38 p. 19-69.

Lehner B., Döll P., Alcamo J., Henrichs T., Kaspar F. 2006. Estimating the impact of global change on flood 
and drought risk in Europe: A continental integrated analysis. Climatic Change. No. 75 p. 273-299.

LIPIŃSKI J. 2015. Efektywność nawadniania kroplowego sadów jabłoniowych na glebach lekkich [The economy of apple orchards drop irrigation on light soils]. Wiadomości Melioracyjne i Łąkarskie. Nr 2 p. 71-75.

Lloyd-Hughes B., SAunders M.A. 2002. A drought climatology for Europe. International Journal of Climatology. Vol. 22. Iss. 13 p. 1571-1592. DOI: 10.1002/joc.846.

ŁABĘDZKI L. 2006. Susze rolnicze - zarys problematyki oraz metody monitorowania i klasyfikacji [Agricultural droughts - an outline of problems and methods of monitoring and classification]. Woda-Środowisko-Obszary Wiejskie. Rozprawy naukowe i monografie. $\mathrm{Nr} 17$. ISBN 83-88763-63-6 pp. 107.

ŁABĘDZKI L. 2007. Irrigation in Poland - current status after reforms in agriculture and future development. Journal of Water and Land Development. No. 11 p. 3-16.

ŁABĘDZKI L. 2009. Droughts in Poland - their impacts on agriculture and mitigation measures. In: Climate change and agriculture in Poland - impacts, mitigation and adaptation measures. Ed. J. Leśny. Acta Agrophysica. Rozprawy i Monografie. Nr 169 p. 97-107.

ŁABĘDZKI L. 2015. Rozwój melioracji i gospodarowania wodą $\mathrm{w}$ świetle opracowań strategicznych województwa kujawsko-pomorskiego. W: Rozwój melioracji i gospodarowania wodą $\mathrm{w}$ świetle wojewódzkich opracowań strategicznych [Developmet of melioration and water management in view of the strategic plans of the $\mathrm{Ku}-$ jawsko-Pomorskie province. In: Development of melioration and water management in view of provincial strategic plans]. Ed. E. Kaca. Woda-Środowisko-Obszary Wiejskie. Rozprawy naukowe i monografie. Nr 38 p. $101-115$.

ŁABĘDZKI L., BĄK B. 2015. Recommendations for operational support system in drought risk management with reference to agricultural drought. Report. International Project „Central and eastern Europe integrated drought management programme". Global Water Partnership. Agreement No. 46-IDMP-2013 pp. 13.

MARACCHI G. 2000. Agricultural drought - a practical approach to definition, assessment and mitigation strategies. In: Drought and drought mitigation in Europe. Eds. J.V. Vogt, F. Somma. Dordrecht. Kluwer Acad. Publ. p. $63-75$.

Pereira L.S., Cordery I., Iacovides I. 2002. Coping with water scarcity. UNESCO IHP VI, Technical Documents in Hydrology. No. 58. Paris. UNESCO pp. 269.

Richter G.M., SEMENOV M.A. 2005. Modelling impacts of climate change on wheat yields in England and Wales: assessing drought risks. Agricultural Systems. Vol. 84. Iss. 1 p. 77-97. DOI: 10.1016/j.agsy.2004.06.011

Slejko M., Bergant K., Gregorič G., Stanič S. 2011. Assessing and mapping crop vulnerability to drought using multi-criteria method. European Geoscience Union General Assembly 2011, Vienna, Austria, 03-08 April 2011, Geophysical Research Abstracts. Vol. 13.

Slejko M., Stanič S., Bergant K., Gregorič G. 2012. Protection of agriculture against drought in Slovenia based on vulnerability and risk assessment. 9th European Geoscience Union General Assembly 2012, Vienna, Austria, 22-27 April 2012, Geophysical Research Abstracts. Vol. 14.

Wilhelmi O.V., WiLhite D.A. 2002. Assessing vulnerability to agricultural drought: a Nebraska case study. Natural Hazards. Vol. 25. Iss. 1 p. 37-58.

Wilhite D.A., Sivakumar M.V.K., Pulwarty R. 2014. Managing drought risk in a changing climate: The role of national drought policy. Weather and Climate Extremes. Vol. 3 p. 4-13.

\section{Leszek LABĘDZKI}

\section{Działania i środki lagodzące skutki niedoboru wody w rolnictwie}

\section{STRESZCZENIE}

\section{Słowa kluczowe: łagodzenie skutków, niedobór wody, rolnictwo, susza}

Scharakteryzowano zjawiska suszy i niedoboru wody w polskim rolnictwie i ich wpływ na plonowanie. Powinny być podjęte różne środki zapobiegawcze w celu ograniczenia szkodliwych skutków suszy i niedoboru wody. Najważniejsze jest zwiększanie zasobów wodnych na terenach rolniczych. Aby osiągnąć ten cel, powinny być nadal realizowane w wielu województwach Polski programy małej retencji wodnej i rozwoju nawodnień. Efektywne wykorzystanie wody do nawodnień, optymalizacja dystrybucji wody, odpowiedni płodozmian, odbudowa i modernizacja istniejących systemów nawadniania, poprawa zdolności retencyjnych gleb to przykłady innych działań. Zapotrzebowanie na wodę nasila się w Polsce. Dlatego istnieje pilna potrzeba opracowania i wdrożenia jednolitych krajowych planów łagodzenia skutków niedoboru wody i susz, w tym wytycznych w celu zapobiegania i przeciwdziałania skutkom niedoboru wody w rolnictwie i wydania zaleceń odnośnie do najbardziej odpowiednich środków, które mogę być podjęte. 